\title{
WWW システムを用いた農作業日誌データベースの開発
}

\author{
河野司 $*$ 二宮正士 ${ }^{* *} \cdot$ 町田武美 ${ }^{* * *} \cdot$ 森泉昭治 $* * *$
}

* 東京農工大学大学院連合農学研究科, $\bar{T}$ 183-0054 東京都府中市幸町 3-5-8 ** 農業研究センター, T 305-0856 茨城県つくば市観音台 3-1-1

*** 茨城大学農学部, $=300-0332$ 茨城県稲敷郡阿見町阿見中央 3-21-1

\section{要旨}

農作物の画像情報,気象情報, 農作業日誌を統合して管理するデータベースをWWシステムを用いて 開発した.サーバには1台のパーソナルコンピュータを用い, ビデオカメラ,気象ロボット,データベー ス, WWWサーバのすべての管理を行った. データベースは, ビデオカメラ, 気像観測ロボットが定期的 に取得する画像デー夕と気象デー夕,栽培管理者が入力する農作業日誌デー夕によって構成される.日 誌入力, データ検索プログラムはCGIスクリプトで開発し, それらのユーザインターフェースにはWeb ブラウザを用いた.

本システムの試験運用の結果, 病虫害や台風による作物の損傷などが記録された.これらの症例や発 生事由を日誌に記録しておくことで, 事象をキーワードとして画像データ,気象データの検索が可能と なり,より効果的な生育分析が可能となった.

キーワード

WWW, CGI, 農作業日誌, データベース, インターネット,ビデオカメラ, 気像観測ロボット

\section{1 緒言}

日々行われる農作業の内容を記録した農作業日誌は，後に農作業分析を行い運営計画を 立てるための重要な資料として用いられる。現在はパーソナルコンピュータ(以下 PC) 等の 情報機器が個人経営農家にも普及し，農作業日誌は農家経営支援ソフトウェア等に見られ る，計算機による複雑な集計，分析が容易に行えるデータとして記録されている.

しかし，現在の農作業日誌に特化したアプリケーションは農作業の労働管理に重点を おいたものが多く，農作物栽培技術の観点での日誌の作成，分析には至っていない.

本研究では, 二宮らによるWWW 圃場画像獲得システム2)を発展させ, カメラによる画像 情報，気象観測ロボットによる気象情報，栽培管理者が入力する日誌，という性質の異な る情報を統合管理する農作業日誌データベースシステムを構築した。本システムの適用に より, 生育分析, 栽培技術の向上, 作業の効率化を行い, 営農計画立案支援の手段として の有効性を探ることを本研究の目的とした。

また，このデータベースをインターネット技術と組み合わせることにより，遠隔地との 
データの共有が可能となる.したがって, インターネットの普及によって可能となった農 業生産組織内や農業生産者間での情報共有により生じる効果についても検討した。ネット ワークを介した農作業支援システムとしては, 既に電子メールとWWW システムを用いたカ ウンセリングが一部の作物で行われている.これは, 効果的なカウンセリングシステムで はあるが，個別の質問に対して個別の回答を得るというシステムで運営されており，必ず しも効率の良いものではない。このようなカウンセリングシステムを効率的に構築, 運営 する手法についても考察した。

なお, 本研究は農林水産省農業研究センター研究情報部と農業インターネット協議会の 共同研究として行われた。

\section{2 農作業日誌データベースについて}

本研究の農作業日誌データベースは，「農作物生育観察データベース」として試験運用 中である．現在稼働中のシステムの構成を表 1 に示す.

このシステムは屋外で鉢植えの作物を栽培し，その脇に設置した気象観測ロボットと， 屋内に設置したビデオカメラを用いて生育の様子を観測している.

サーバとなるPCを屋内に設置し，観測に用いるビデオカメラと気象観測ロボットを制御 し，得られた画像データと気象データを管理している．同時に栽培管理者から入力される 農作業日誌のデータも管理している．さらに，このサーバPCはWWWサーバも兼ねており， 管理しているデータをネットワークで提供できる。

表1 試験運用中の農作業日誌データベースの構成

\begin{tabular}{|c|c|}
\hline サーバPC & $\begin{array}{l}\text { CPU Intel Pentium133MHz } \\
\text { HDD EIDE 2.3Gbyte } \\
\text { RAM FastPageSIMM 16Mbyte } \times 2 \\
\text { マザーボード GIGABYTE GA-586HX } \\
\text { ビデオカード Canopus PowerliindowDX/4MC } \\
\text { ネットワークカード NextCom 3C509B-TP }\end{array}$ \\
\hline 気象ロボット & 明星電気 WINS \\
\hline ビデオカメラ & Canon VC-C1 MK2 \\
\hline ソフトウェア & $\begin{array}{l}\text { Microsoft Windows } 95 \text {, Microsoft Personal } \\
\text { Web Server, Hip communication inc. } \\
\text { PerlIIS.dll }\end{array}$ \\
\hline $\begin{array}{l}\text { 気象データロガとの通信プロ } \\
\text { グラム }\end{array}$ & Visual Basic4.0で作成 \\
\hline カメラ制御プログラム & $\begin{array}{l}\text { カメラとの通信部はVisual } \mathrm{C} / \mathrm{C}_{++2} .0 \text {, データ } \\
\text { ベースとのインターフェース部はV i s u a l } \\
\text { Basic4.0で作成 }\end{array}$ \\
\hline $\begin{array}{l}\text { 日誌入力プログラム } \\
\text { データ検索·表示プログラム }\end{array}$ & $\begin{array}{l}\text { Perl for Win32で作成(CGI スクリプト) } \\
\text { Perl for Win32で作成(CGI スクリプト) }\end{array}$ \\
\hline
\end{tabular}




\section{1 ) ハードゥェアシステム}

本システムのハードウェア構成を図 1 に示す.

サーバPCには現在もっとも一般的な PC/AT 互換機を用いた。気象ロボットとビデオカメ ラの制御は，このPCのシリアルポートを経由して行う.

気象観測ロボットは午前 0 時から 10 分おきの定時データとして, 風向, 風速, 気温, 湿 度, 全天日射を観測し, 1 日の極值データとして瞬間最大風速, 発生時風向, 最高気温, 最 低気温, 最高湿度, 最低湿度とそれぞれが起こった時間を気象観測ロボットに付属のデー タロガに保存する。

ビデオカメラには雲台付き小型ビデオカメラのCanon VC-C1 MK2 を用いる。この機種 はサーバPCからシリアルポート経由で, 撮影時の角度, 倍率などを細かく指定することが できる.ここで撮影されている画像は, カメラのNTSC 端子を通して常時サーバPCのビデ オキャプチャボードへ送られる。

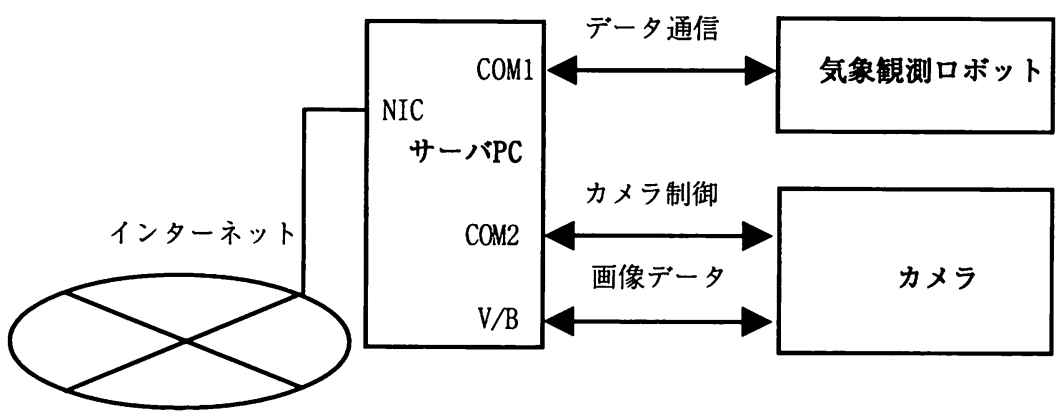

\footnotetext{
NICはネットワークインターフェースカード

COM1, COM2はシリアルポート

V/Bはビデオキャプチャボード
}

図1農作物生育観察データベースのハードウェア構成

\section{2 ) ソフトウェアシステム}

本システムのソフトウェア構成を図 2 に示す.

OSにはWindows95を用いた。 WWWサーバプログラムにはMicrosoft Personal Web Serverを使用し, Perl 言語によるCGI (Common Gateway Interface)スクリプトを実行 するためのISAPI(Internet Server Application Programming Interface)には PerlIIS.dllを用いた。

気象観測ロボットとの通信プログラムはVisual Basic4.0を用いて開発した。このプ ログラムはシリアルポート経由で観測したデータを格納しているデータロガと通信し, データを固定長テキスト形式でサーバPCに保存する。

カメラ制御プログラムは, シリアルポート経由で雲台の角度やカメラの倍率を操作し, 静止画像を保存する，角度は基準位置から左右各 50 度, 水平位置から上下各 20 度の範囲 
で 1 度刻みの指定ができ, 倍率は 1 倍から 8 倍の間を 128 段階で指定できる. 画像の解像 度は $160 \times 120 ， 320 \times 240 ， 640 \times 480$ ドットの中から選択できる．画像フォーマットに は圧縮率に優れ，一般的な Web ブラウザで表示可能な JPEG を採用した。 このプログラムは 直接カメラと通信する部分をWWW 固場画像獲得システムで開発されたものを用い，ユーザ 側で角度，倍率，解像度等の設定を行う部分をVisual Basic4.0で新たに開発した。

上記 2 つのプログラムをそれぞれ定時実行するために，タイマーソフトを利用した。こ のタイマーソフトは実行している間，あらかじめ登録しておいたプログラムを指定した時 間に起動する機能を持つ。さらに, Windows95 のレジストリファイルを操作することによ り, このプログラムをサーバ PC 起動後のログオン待ち画面で実行させた。これによりシス テムが不安定になってもサーバPCを再起動することで稼働状態に復帰することができ, 遠 隔管理が容易となる。

農作業日誌入力プログラムはPerl 言語で開発した。このプログラムはCGI スクリプトで あり，データの入力はWeb ブラウザで行う．入力されたデータは年月日によりファイル名 が決定され，テキスト形式で保存される。

データ検索，表示プログラムも Perl 言語で開発したCGI スクリプトであり, Web ブラウ ザから実行する．記録された各デー夕を時系列で表示する機能のほか, 作物名, 日時, 任 意のキーワード(例えば, 開花等の現象名, 摘果等の作業名)等で条件を与え, 該当する画 像, 気象，日誌の各デー夕を検索し，一覧表示する機能がある.

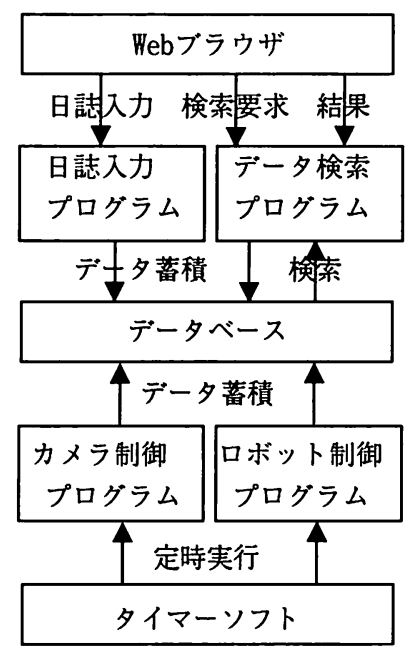

図2＼cjkstart農作物生育観察データベースのソフトウェア構成

\section{3 システムの運用}

現在の試験運用では， 5 種類の作物 (ズッキーニ, ナス,トマト，ピーマン，水稲）を鉢 植えで栽培し，1997 年 5 月下旬から栽培過程のデー夕を時系列で取得した。システムは安 定的に稼動し，現在までに起こった各作物の開花，結実，病虫害等が記録された。 


\section{1 ) 取得データ}

\section{(1) 気象データ}

気象データは気象観測ロボットとの通信プログラムにより, 毎日午前 1 時に前日分の データを一括してサーバPCに保存する設定とした。

図 3 は 1997 年 6 月 17 日分の記録されたデータの一部, 表 2 はファイル形式の解説であ る. 10 分ごとに計測されたデータが1行ごとに記録される．風向と風速は過去 10 分間の 平均であり，他の気象項目は計測時の瞬時データである.

\begin{tabular}{|c|c|c|c|c|}
\hline 19970617152000WD & 04WS & 019AT & $+227 \mathrm{RH}$ & 0668IS 08150 \\
\hline 19970617153000WD & 04WS & $015 \mathrm{AT}$ & $+226 \mathrm{RH}$ & 0686IS 07235 \\
\hline 19970617154000WD & 04WS & 016AT & $+224 \mathrm{RH}$ & 0675IS 07245 \\
\hline 19970617155000WD & 04WS & 015AT & $+226 \mathrm{RH}$ & 0659IS 07698 \\
\hline $19970617160000 \mathrm{KD}$ & 04WS & 019AT & $+222 \mathrm{RH}$ & 0684IS 07181 \\
\hline 19970617161000KD & 04WS & 019AT & $+221 \mathrm{RH}$ & 0677IS 05484 \\
\hline $19970617162000 \mathrm{WD}$ & 04WS & 019AT & $+220 \mathrm{RH}$ & 0690IS 05352 \\
\hline 19970617163000HD & 04WS & 020AT & $+220 \mathrm{RH}$ & 0681IS 05178 \\
\hline 19970617164000KD & 04WS & $016 \mathrm{AT}$ & $+219 \mathrm{RH}$ & 0697IS 04507 \\
\hline 19970617165000WD & $04 \mathrm{WS}$ & 017AT & $+217 \mathrm{RH}$ & 0693IS 03611 \\
\hline 19970617170000KD & 04WS & 018AT & $+219 \mathrm{RH}$ & 0697IS 03619 \\
\hline 19970617171000WD & 04WS & 021AT & $+216 \mathrm{RH}$ & 0714IS 02851 \\
\hline
\end{tabular}

図3 1997年6月17日の気象データ(一部抜粋)

表2 気象データファイル形式

\begin{tabular}{|l|l|l|l|}
\hline 列 & 意味 & 例 & 值 \\
\hline $1 \sim 8$ 列 & 年,月,日 & 19970617 & 1997 年6月17日 \\
\hline $9 \sim 14$ 列 & 時,分,秒 & 152000 & 15 時20分0秒 \\
\hline $15 \sim 22$ 列 & 風向 & WD 04 & 東* $^{*}$ \\
\hline $23 \sim 30$ 列 & 風速 & WS 019 & $1.9 \mathrm{~m} / \mathrm{s}$ \\
\hline $31 \sim 38$ 列 & 気温 & AT +227 & $22.7^{\circ} \mathrm{C}$ \\
\hline $39 \sim 46$ 列 & 相対湿度 & RH 0668 & $66.8 \%$ \\
\hline $47 \sim 54$ 列 & 全天日射 & IS 08150 & $81.5 \mathrm{KJ} / \mathrm{m}^{2}$ \\
\hline
\end{tabular}

*01 が北北東, 以降 16 方位に沿って時計周りに方向を示し, 最大値の 16 が北となる

\section{(2) 画像データ}

画像データは毎日の時刻 8:00,12:00，16:00に5つの作物を撮影, 取得した。この設 定は撮影時間の有効性を探るための試行的なものである.1 回の撮影で各作物につき 1 倍, 4 倍, 8 倍の倍率と $160 \times 120,640 \times 480$ ドットの解像度で各 6 枚づつ JPEG 形式で保存し た. 1 日分のデータは 90 ファイルで約 $1.5 \mathrm{M}$ バイトであった. 
図 4 はズッキーニを 1997 年 6 月 15 日 16 時に 4 倍, 解像度 $640 \times 480$ ドットで撮影した ものである。画像ファイルの名前は撮影した年月日，時間，倍率，解像度によって決定さ れ，あらかじめ設定した作物ごとのディレクトリに保存される。作物ごとのディレクトリ は撮影角度順に p0, p1，p2，p3，p4 と設定した。したがって，この画像のファイル名は 1997061516_64_640.jpgとなり，ズッキーニ専用のp0 というディレクトリに保存された。

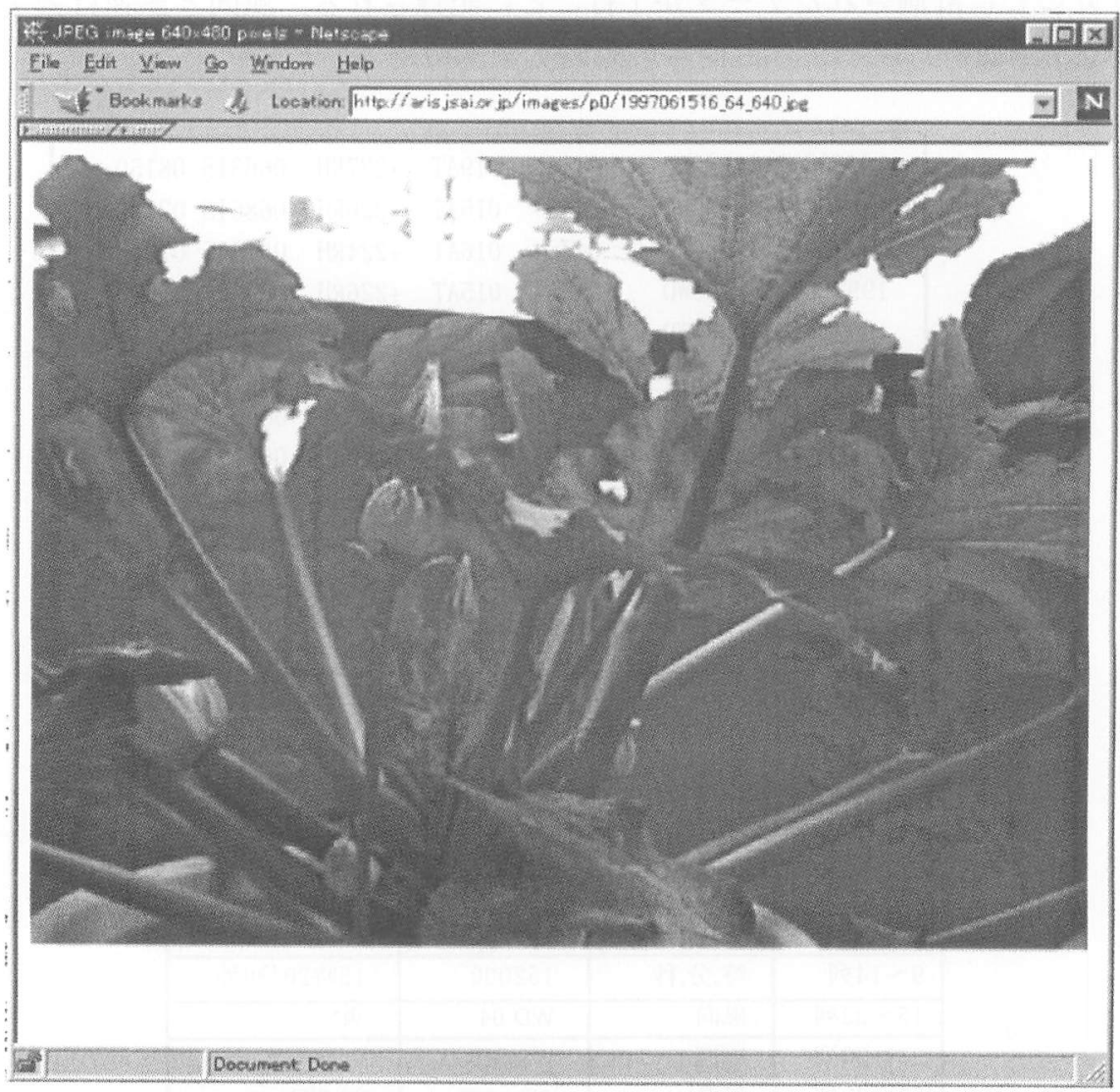

図4 ズーム4倍, 解像度 $640 \times 480$ ドットのズッキーニの画像

(1997年6月15日16時)

\section{（３）農作業日誌データ}

農作業日誌データはWebブラウザから入力した，図 5 はその入力画面であり，図 6 は 1997 年 6 月 13 日分のデータである.ファイル名は年月日によって決定され，この場合は 19970613 である. 入力項目は日誌記入者, 見出し, 日付, 内容の項目がある。入力された 項目はそれぞれあらかじめ設定したHTML(Hypertext Markup Language)夕グを挿入する ことにより分類され，最後には段落を示すくP>夕グが挿入される。文書にHTML夕グを用い て属性を与えることにより, Web ブラウザで表示する際の文書整形が容易となる。また， 入力項目が流動的で内容も非定型的なデータにおいても，計算機を用いた一括処理が容易 であるという利点がある。 


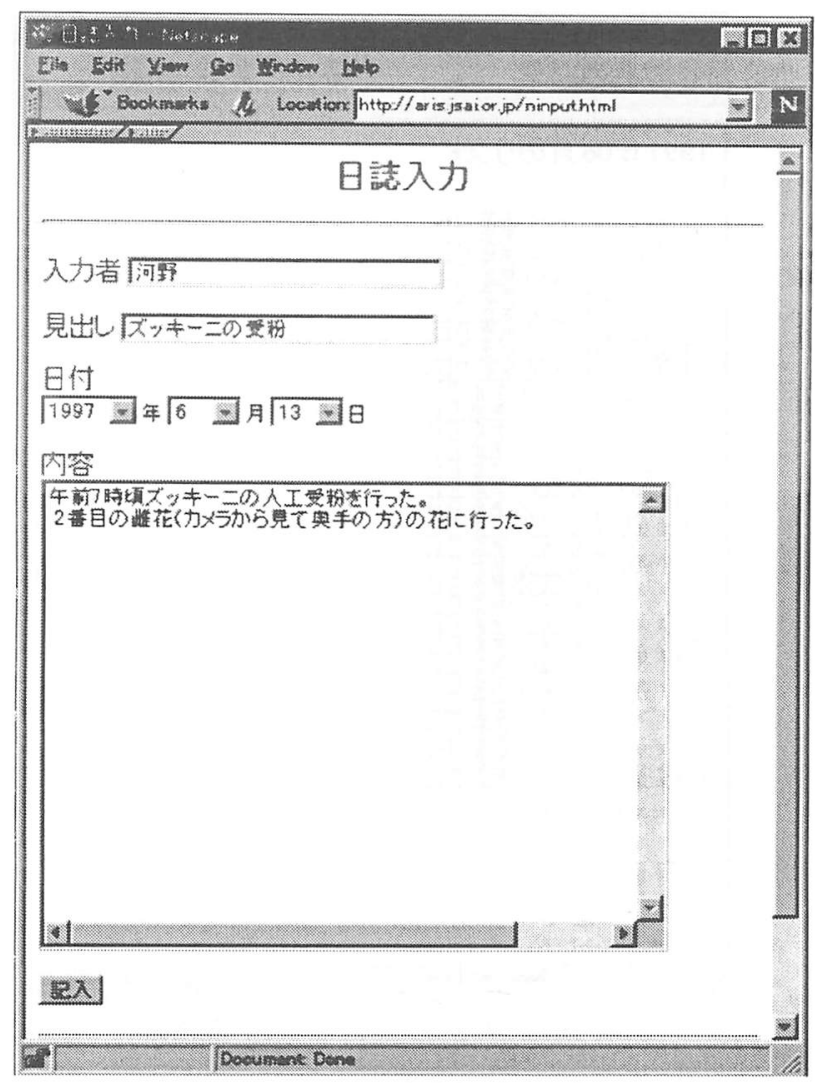

図 5 農作業日誌入力画面

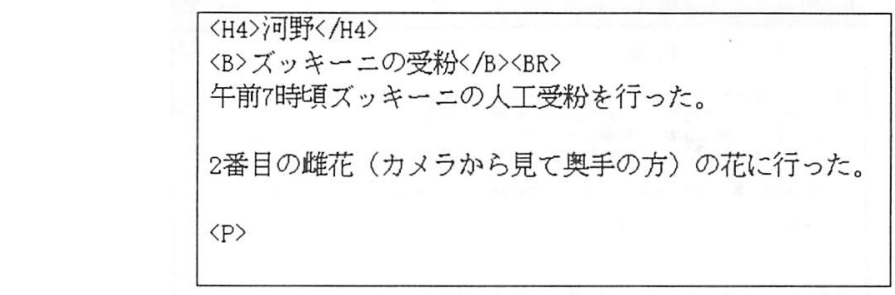

$<\mathrm{H} 4></ \mathrm{H} 4>$ で囲ま机ている部分は記入者名, $\langle\mathrm{B}></ B>$ は見出し, 以降は内容部分 図6 1997年6月13日分の日誌

\section{2 ) データ検索，表示}

本システムの検索表示機能には，取得したデー夕を記録時間ごとで一覧表示する「ファ イルリスト一覧」(図 7 参照) と, 作物名, 日時, 任意のキーワード等で画像, 気象, 日誌の 各データを検索, 表示する「データベース検索」(図 8 参照)がある.

「ファイルリスト一覧」では1ヶ月ごとにリストが表示され，毎日 8:00，12:00，16:00 の時刻に撮影した画像と, 1 日分の気象データ, 日誌データが参照できる。図 9 は 1997 年 6 月 13 日の 16 時に撮影した画像の一覧例である.この時に一覧表示される画像は解像度 $160 \times 120$ ドットで撮影されたものであり，この画像をクリックすることで同時刻同角度 において撮影された図 4 のような解像度 $640 \times 480$ ドットの詳細画像を表示する。 


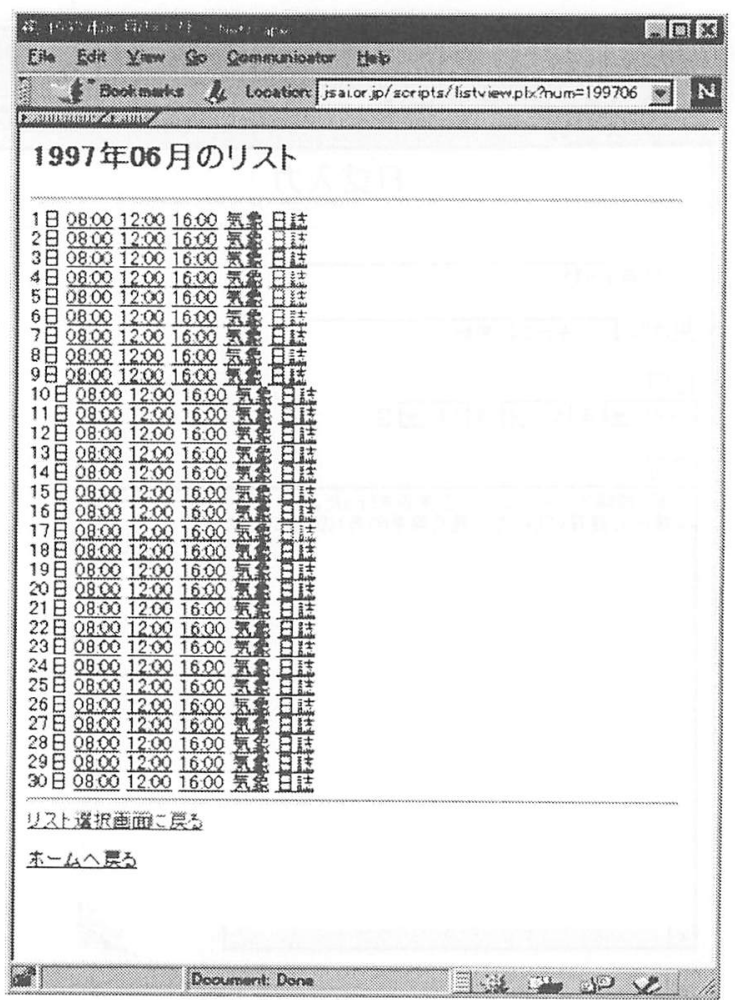

図7 6月分ファイルリスト一覧画面

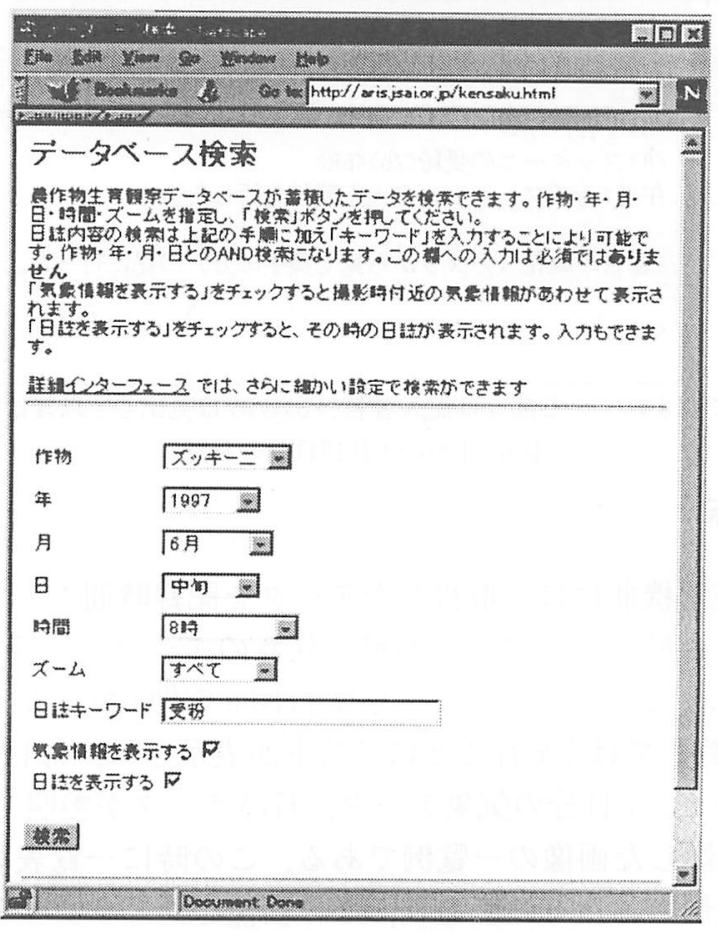

図8 データベース検索画面 
「データベース検索」では，検索対象の作物，期間，画像の撮影時間，ズーム，日誌内 容に対するキーワードを指定して検索ができる。期間は単年, 単月, 単日だけでなく, 全 ての期間や上旬，中旬，下旬などの指定もでき，検索方法によっては毎年同時期の比較や ある作業内容についての比較ができる。

図 10 は図 8 で入力されている条件で検索した結果である。検索プログラムは与えられた 検索条件から，作物がズッキーニで時期が1997 年 6 月中旬かつ日誌に「受粉」という文字 列が含まれている日を抽出する。 その後, 該当する日の $8: 00$ に撮影されたすべてのズー ムの画像と気象データを表示する。日誌の下に表示されている「日誌記入」をクリックす ると，日誌を追加入力することができる。

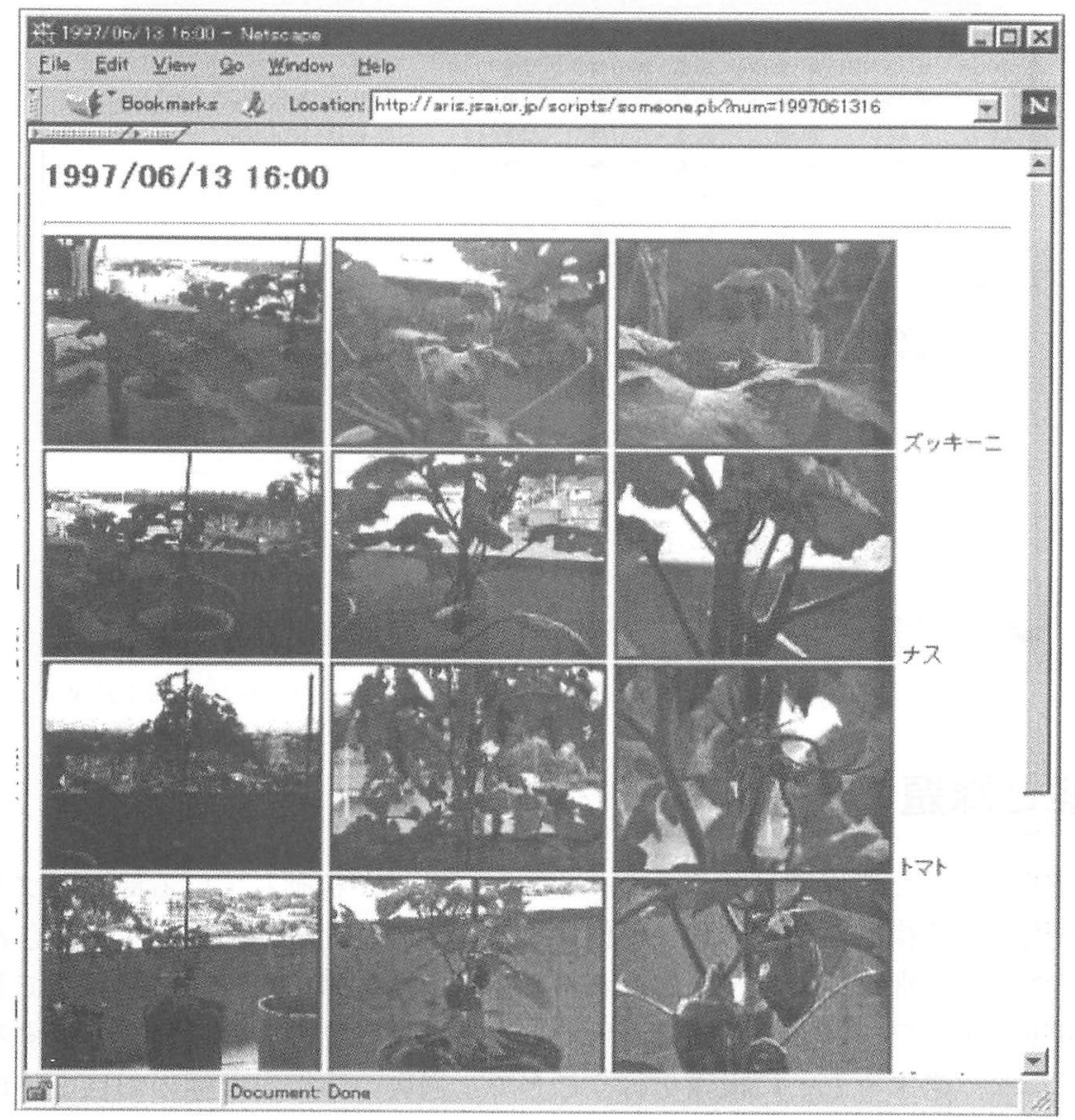

図9 1997年6月13日16時に撮影した画像の一覧 


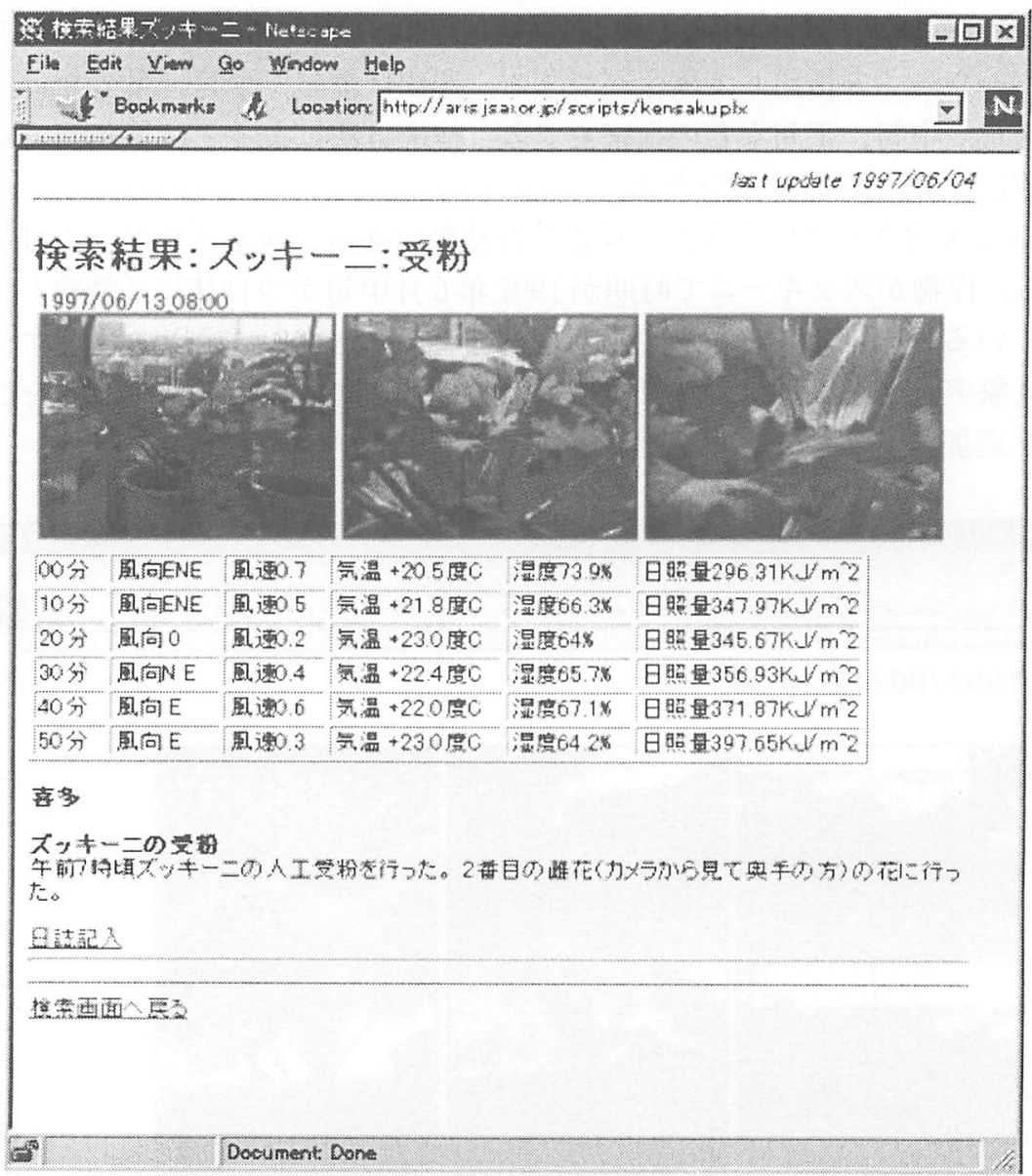

図10 1997年6月中旬, 作物ズッキーニ, 日誌キーワード「受粉」での検索結果

\section{4 考察と課題}

本研究で試行した農作業日誌データベースシステムが稼動している間，アブラムシによ る害や台風による損壊，栽培管理の不供による作物の枯死等が発生し，記録されている画 像データからも判別可能であった。これらの症例や発生事由を日誌に記録しておくことに より，事象をキーワードとした検索が可能となった。作物の生育過程を分析する際に時系 列だけでなく，事象をもとに検索を行うことで，過去の事例を共通の項目で整理し，ょり 効果的な比較検討をする事が可能となった。

このように作物の生育過程の画像データと, 環境条件である気象デー夕を蓄積したもの は, 生育診断の材料となる。例えば, 開花から結実までの作物画像とその間の気温，日射 量との関連を探り, 収穫時期予測や病虫害発生予測を行うことが考えられる。その生育診 断の結果を, 過去のデータ, 他の戋場の結果, 作物生育モデル, 栽培暦等と比較すること で現在の作物の状況を把握できる。その上で, 現在および将来において必要な作業を導き 出し, 農作業計画, 経営計画に反映させることで, より効率的な生産活動が可能である. 
さらに，その都度行った作業内容を日誌データとして記録することで，具体的事例を統 合した知識データベースが構築される. 成功事例, 失敗事例とも含めた総合的な農作業日 誌データベースの検索は，意思決定の際に過去の経験や勘に依存する部分を代替できる. そのデータベースを利用し, 経験の浅い農家が優秀な農家の技術を模倣することで, 栽培 技術の向上が可能である。 また, 基準となる栽培モデルに沿った作業を農業生産組織内で 行い, 生産物の品質を安定させることも考えられる.

緒言で述べた電子メールとWWW システムによるカウンセリングシステムでは, 症状が顕 在化した後の画像上書面で作物の状態を伝える診断を行う. 本システムを適用すると, 症 例が顕在化する以前の画像データや生育課程の気象データもカウンセリングの材料となる. 試験運用中の台風による損壊の例では，前日までの画像と当日の強風が記録されていたた め原因の特定が容易であった。

またカウンセラがネットワーク経由で本システムにアクセスすることにより，事務所に いながら地理的に離れた圑場の症例を効率よく検索，診断することが可能である.

インターネットを利用することで固場の遠隔管理, 計測機器の遠隔制御が可能となる. 大規模戋場に複数の観測機器を設置し，集中監視システムの構築が可能である。市街地に 住む市民農園の所有者が，日常的に固場を監視できるシステムも構築可能である。また， 構築したデータベースをインターネットで公開し，栽培課程を消費者に対し明示できる. この適用は農産物に対する信用を深め，生産者と消費者との連携を促し，産直販売や契約 栽培の内容充実につながる。

また，本システムはサーバを 1 台のPCで実現することにより導入コスト負担が少なく， 農業生産組織のほか個人経営農家等にも導入可能であると考える．組織内LAN や非ネット ワーク環境で使用するのであれば必ずしもインターネットに接続する必要はない。遠隔地 からの操作も電話回線経由で直接サーバPCにダイアルアップ接続することにより可能であ る. WWW システムの CGI 技術をデータベースの日誌入力, データ検索部分に採用した理由 は，ネットワークとの親和性を考慮してのものである。しかしこれは，結果的にユーザイ ンターフェースをWeb ブラウザに統一することになり，コンピュータ操作技術の習得にか かる手間を軽隇させる補助効果も期待できる。

さらに，ネットワーク上に存在する市況や種苗などを扱う種々のデータベース ${ }^{3)-8)}$ と検 索分析インターフェースを統合することで, 症例から対処法, 資材まで検索できる農業生 産支援システムが構築可能と考える.

本研究は現時点においてシステムの試用にとどまっており，今後どのような農作業現場 へ適用し，どのような分析ができるのかを検討する必要がある。現段階では作物が高密度 で栽培され，気象的に閉鎖空間である施設栽培への適用が実用面で最も有望である。

生育診断ではさらに詳細な情報を必要とする場合があり，赤外線カメラによる温度観測 や複数のカメラによる立体視等の適用が課題となる.

本システムが知識データベースとして農作業支援システムとなりうるには，得られた データを複数年間蓄積し比較検討分析に耐えうる十分なデータ量となった時に，より適切 な検索, 分析システムに改良することが必要である。作物や圃場環境などが異なる場合, その分析手法は異なるため, 現場への適用事例をもって開花予測や防除時期の判断等の具 
体的な分析手法を確立することや，ネットワークを介した他のデータベースとの連携も今 後の課題である.

\section{謝辞}

本システムの開発, 運用において協力をいたたいた農業情報利用研究会事務局長の田上 隆一氏, 筑波大学の喜多剛志氏, 筑波大学大学院の稲畑健英氏に謝意を表します.

\section{引用文献}

1）ソリマチ株式会社・塩光輝監修(1993)，農作業日誌分析Ver.3，ソリマチ株式会社

2) 二宮正士・木浦卓治・江渡浩一郎・南石晃明・上田正和(1996), WWW固場画像獲得システム, 植物工場学会誌, $9(1), 12-19$

3）二宮正士・屋良佳緒利・江渡浩一郎 - 山本謙治 - 南石晃明 - 渡辺達三 · 大森宏(1994)：検索機能を持つHWW画像 データベース「Lotus in Japan(日本の蓮)」の構築, 農業情報研究, 3(2)，49-66

4）江渡浩一郎・山本謙治・南石晃明・二宮正士(1994)：WWWに対応した青果物市況データベース"NAPASS for Web" の開発-既存データベースを利用した検索機能の実現と検索結果の視覚化, 農業情報研究, 3(2), 127-141

5）河野司・南石晃明・二宮正士・谷口晋(1996)：WWWにおける簡易情報検索ツール「Wgrep」の開発と青果物情報デー タベースへの適用, 農業情報研究, 5(1), 1-18

6）中谷誠・南石晃明・河野司(1996)：WWWおよびHyperCardによる新作物導入支援資源作物画像データベースの作 成, 農業情報研究, $5(2), 69-83$

7）南石晃明・牧野和佳・上田正和・下村道彦・平藤雅之(1977)：Java言語による対話的グラフ表示機能を備えたWWW 青果物市況データベースNAPASS for Web on Javaの開発, 農業情報研究, 6(1)，27-42

8）二宮正士・遠藤勲・斎藤元也·美濃伸之 -小川茂男・江渡浩一郎・山本健治・南石晃明(1997) : WWW 衛星画像 カタログデータベースの構築, システム農学, 13(1), 24-31 


\title{
Development of Farm-working Journal Database on WWW
}

\section{Tsukasa Kouno*, Seishi Ninomiya**, Takemi Machida*** and Shoji Moriizumi***}

\author{
*Doctoral Course in Agricultural Science, Tokyo University of Agriculture and Technology, \\ Saiwai 3-5-8, Fuchu, Tokyo, 183-0054, Japan \\ **National Agriculture Research Center,Kannondai 3-1-1,Tsukuba, Ibaraki, 305-0856, Japan \\ ***School of Agriculture, Ibaraki University,Chuou 3-21-1, Ami, Inashiki, Ibaraki 300-0332, Japan
}

\section{Summary}

We have developed a farm-working journal database, with which crop-image data, local weather data and working journals kept by farm workers can be collectively controlled on the WWW.

All the data as well as the video camera and the weather robot, which transmit data into the database, are under control of one personal computer functioning as a WWW server with Windows95.

The Web Browsing enables the users to interface with the database since the input system for working-journal data and the data-retrieval tools were developed as CGI-scripts.

The database can be shared through a computer network by agricultural product organizations, local farmers and consumers; accordingly, anticipated can be the improvement of farming techniques including farm-product analysis, farm-work sharing and farm-working instructions.

In Addition, on the World Wide Web, we are planning to relate this database system to others, namely, Crop-database and Market-database. As a result, this can be developed into a collectivesupport system for agricultural production in decision-making.

Keywords:WWW, CGI, farm-working journal, database, Internet, video camera, weather robot 